\title{
Perceived Drivers Of Green Practices Adoption: A Conceptual Framework
}

Chai Har Lee, MBA, Multimedia University, Malaysia

Nabsiah Abdul Wahid, Ph.D., Universiti Sains Malaysia, Malaysia

Yen Nee Goh, DBA, Universiti Sains Malaysia, Malaysia

\begin{abstract}
With respect to the rapidly increasing importance of environmental issues, there is a need for businesses from various industries, including the food service industry, to implement initiatives to go green. In Malaysia, green fast-food restaurants are a growing niche. Being green is a strategy to differentiate a business from other competitors in the industry. Being green also indicates a positive response to consumers' demand for environmentally friendly organizations. The food service industry, however, appears to be less inclined to adopt green practices than other industries. Most of the literature on green practices investigates the subject matter from consumers' perspective, rather than from organizations' perspective. This paper provides a conceptual framework on the adoption of the drivers of green practices for fast-food restaurants, with institutional theory as its underlying base. In this paper, perceived internal (i.e., normative pressure) and external drivers (i.e., coercive pressure and mimetic pressure) are considered to be the drivers. Normative pressure is represented by pressure from employees and manager's attributes; coercive pressure is represented by regulatory pressure and customer pressure; and mimetic pressure is pressure from competitors. The results of the findings are expected to indicate whether internal and external factors drive the adoption of green practices for fast-food restaurants in Malaysia.
\end{abstract}

Keywords: Green Practices; Institutional Theory; Coercive Pressure; Normative Pressure; Mimetic Pressure

\section{INTRODUCTION}

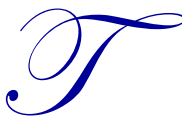

he hospitality and tourism industry is one of the largest and fastest-growing industries in the world (Sulaiman \& Haron, 2011). As a continuously growing sector, the hospitality industry has a social responsibility to contribute to environmental issues and climate change, as natural resources and the physical environment are the most precious assets in that industry (Kasim, 2009). The hospitality industry includes hotels, food services, hospitals, and airlines among its components (Line \& Runyan, 2011). The food service industry in Malaysia has been identified as one of the fastest growing industries in hospitality (Lee et al., 2012). It consumes enormous amounts of energy, water, and other resources. It also produces large amounts of waste and generates different types of pollution in its daily operations. Malaysia is an ecologically rich destination (Siti-Nabiha et al., 2011), but if food service organizations do not take appropriate measures, then the country's precious natural resources and the physical environment will be destroyed. The adoption of green practices within food service organizations to solve this problem has been successful in other countries such as Taiwan (Chou et al., 2012; Wang, 2012) and the United States (Jang et al., 2011). The question now is, if the adoption of green practices has been successful in other countries, should food service organizations in Malaysia adopt similar practices? Another, related question is: What will be the drivers for the adoption of green practices for food service organizations in this country? To answer these questions, this paper will explore possible internal and external drivers for the adoption of green practices in food service organizations. It is hoped that the results can motivate relevant food service organizations to play their roles in incorporating green practices in their daily operations. 


\section{Foodservice industry in Malaysia}

The Government of Malaysia is highly involved in promoting green initiatives for all industries. For years, it has been searching for alternative national sources of energy that have less harmful effects on the environment. The 10th Malaysia Plan states the need to develop a better way of handling resources to keep up with the increasing demand for resources (e.g., energy, water, gas, etc.) for industries. The Plan aims to develop alternative sources of energy and reduce water usage, particularly in the country's food service industry.

According to Euromonitor International (2011), consumer food service in Malaysia is classified into six segments, namely cafés/bars, full-service restaurants, fast food, $100 \%$ home delivery/takeaway, self-service cafeterias, and street stalls. Table 1 shows the number of outlets by each segment from 2006 to 2010, with fast-food displaying the highest growth (8\%) in terms of number of outlets from 2009, followed by self-service cafeterias (6\%). In addition, the Market Analysis Report (2011) shows a significant increase in the number of transactions in the consumer food service industry between 2005 and 2009, at a compound annual growth rate (CAGR) of 6.80\%, with a record of $38.92 \%$ in absolute growth. Fast food is also recorded as the fastest growth segment (CAGR of $11.64 \%$; absolute rate of 7.40\%), followed by the café and bar segment (CAGR of 7.93\%; absolute rate of 46.47\%). In this report, fast food is expected to be the fastest growing segment of the food service industry, with a CAGR of $3.47 \%$ and an absolute growth of $14.60 \%$ for the period 2010 to 2014 .

Table 1. Total Outlets of Food Services by Segments in Malaysia 2006 to 2010

\begin{tabular}{lccccc}
\hline Segments & $\mathbf{2 0 0 6}$ & $\mathbf{2 0 0 7}$ & $\mathbf{2 0 0 8}$ & $\mathbf{2 0 0 9}$ & $\mathbf{2 0 1 0}$ \\
\hline 100\% Home Delivery/Takeaway & 170 & 177 & 189 & 207 & 215 \\
Cafés/Bars & 4,464 & 4,669 & 4,804 & 4,894 & 5,081 \\
Full-Service Restaurants & 9,010 & 9,434 & 9,717 & 9,742 & 9,946 \\
Fast Food & 1,988 & 2,312 & 2,574 & 2,743 & 2,953 \\
Self-Service Cafeterias & 220 & 240 & 258 & 268 & 284 \\
Street Stalls & 10,114 & 10,417 & 10,645 & 10,756 & 10,862 \\
\hline Total Consumer Food service & $\mathbf{2 5 , 9 6 6}$ & $\mathbf{2 7 , 2 4 9}$ & $\mathbf{2 8 , 1 8 7}$ & $\mathbf{2 8 , 6 1 0}$ & $\mathbf{2 9 , 3 4 1}$ \\
\hline
\end{tabular}

Source: Euromonitor International (2011)

As fast-food restaurants are the fastest growing segment of the food service industry in Malaysia, and because restaurants are the retail world's largest energy users (Horovitz, 2008; Lee et al., 2012), the government's initiative to persuade food providers to make serious efforts to adopt green practices to further reduce energy consumption is important.

\section{WHAT ARE GREEN PRACTICES?}

The literature offers diverse definitions of green practices. Mohindra (2008) states that green practices encompass the three Rs: reduce, reuse, and recycle. Manaktola and Jauhari (2007) refer to green practices as the commitment of various sound practices that minimize negative environmental impacts, such as saving energy, saving water, and reducing solid waste. Wang (2012) categorizes green practices into two dimensions. The first is practices customers are exposed to, such as recycling and composting; energy and water-efficient equipment; ecofriendly cleaning supplies and packaging; and menu sustainability. The second dimension relates to practices operated at the back of the house (e.g. using energy-efficient lighting). While opinions vary, the gist remains the same. Clearly, scholars agree that green practices are those one can adopt to reduce harmful effects to the environment.

In line with the opinions above, in this paper green practices refer to practices fast-food restaurants can adopt to reduce the adverse environmental effects of their facilities and operations. Green practices in this study cover seven categories as determined by the Green Restaurants Association (GRA): i) water efficiency, ii) waste reduction and recycling, iii) sustainable furnishings and building materials, iv) sustainable food, v) energy, vi) disposables, vii) chemical and pollution reduction. 


\section{Why green practices?}

In response to the current competitive environment, being green is indeed a business decision rather than a strategy to attract new customers. It has been proved that adopting green practices benefits firms or organizations in various aspects, including human capital. Employees nowadays would prefer to work for a company that creates a greener business environment. (Environmental Leader, 2012).

The literature acknowledges various advantages to the adoption of green practices. These include: business sustainability, cost savings, saving the environment, and better firm reputation. In combination, these advantages ultimately mean that the adoption of green practices can lead to better firm performance.

Firms or organizations adopt green practices to help them achieve sustainability in their business operations. However, according to Norton (2010), sustainability is achieved only when firms or organizations adopt two main green practices: i) consume less resources, such as energy, materials, and water; and ii) shift to an economy that mimics the natural environment by consuming resources that don't poison the economic system; practice recycling activities; and consume energy that is renewable. In addition, Manaktola and Jauhari (2007) argue that firms or organizations adopting green practices to protect the environment are able to position themselves distinctively in the competitive market place. An empirical report by Business and Environment (2008) has also highlighted a significant reduction of between $11 \%$ and $15 \%$ in monthly energy usage among restaurants.

Apart from the aforementioned advantages, firms adopting green practices can opt for green restaurant certification, which provides several benefits, such as greater publicity, reduced costs, improved staff productivity and morale, staying ahead of legislation, and creating a healthy environment (Business and the Environment, 2008). Thus, restaurants need to fulfill seven categories based on points awarded before they can be certified as green. There are three levels of certified green restaurants: two-star, three-star, and four-star. The levels depend on total points obtained, and the restaurant is then evaluated based on the green practices it employs. To date, Malaysia does not have an association that grants green certificates to restaurants that fulfill the criteria of a certified green restaurant. In spite of this situation, empirical evidence has proved that the adoption of green practices indeed brings significant advantages to firms or organizations. At this juncture, the research questions advanced in this paper are indeed appropriate for the context of the study.

\section{UNDERPINNING THEORY AND PROPOSED FRAMEWORK}

\section{Institutional Theory}

Institutional theory, which suggests that organizations are social systems, is used as a theoretical framework to explain why organizations adopt practices, policies, and procedures (DiMaggio \& Powell, 1983; Meyer \& Rowan, 1977 cited from Scott, 2001).

Institutional theory conveys how organizations should behave (Hatch, 1997; Powell \& DiMaggio, 1991; Scott, 1995) and how organizations should take action in response to environmental pressures (Grewal \& Dharwadkar, 2002; Hoffman, 1997; Scott, 2001) that are beyond their control (Hoffman, 1977). Institutional theory also answers questions concerning institutional influence on social choices (Powell \& DiMaggio, 1991). Moreover, institutional theory posits that organizations are not only production systems but also include social and cultural systems (Scott, 2001). Organization choices and actions are constrained and influenced by social behaviors, norms, and values within the environment (Selznick, 1957). Hence, organizations sometimes have the desire and need to adopt and adhere to rules and practices created from environmental pressure, which may not be the organization's original intent.

Based on institutional theory, organizations conform to institutional pressures to gain legitimacy, which may enhance their survival (Meyer \& Rowan, 1977). Legitimacy is defined as "a perception that the actions of an entity are desirable, proper, or appropriate within some socially constructed system of norms, values, beliefs, and definitions" (Suchman, 1995, p. 574). In other words, legitimacy is the belief that certain behaviors or practices are something everyone in the environment should engage in. However, Schelling (1978) observes that organizations 
are under pressure to conform to norms of practices and policies that are isomorphic within the environment in which they operate. Isomorphism refers to the process in which organizations begin to modify their organizational characteristics to conform with others to increase compatibility with environmental characteristics. Therefore, when organizations adopt practices that are legitimate to the environment, isomorphism is achieved and survival is often higher (Zucker, 1987). DiMaggio and Powell (1983) identify two types of isomorphism: competitive and institutional. Competitive isomorphism is most relevant in a free and open competition market because it emphasizes market competition, niche change, and fitness measure; however, it does not explain the modern world of organizations (DiMaggio \& Powell, 1983). To complement the limitation of competitive isomorphism, DiMaggio and Powell (1983) reveal that the concept of institutional isomorphism is a more useful tool to understand modern organizational life. This is supplemented by the view of Aldrich (1979) that an organization must take into account other organizations. According to Carroll and Delacroix (1982), organizations competing for resources and customers is not sufficient; organizations need to compete for political power and institutional legitimacy to achieve social as well as economic rewards. Institutional isomorphism occurs through three mechanisms, namely coercive pressure, normative pressure, and mimetic pressure.

\section{Coercive Pressure}

Coercive isomorphism stems from "formal and informal pressures exerted on organizations by other organizations upon which they are dependent and by cultural expectations in the society within which organizations function" (DiMaggio \& Powell, 1983, pp. 150). These pressures can arise from government regulations or laws (DiMaggio \& Powell, 1983); customers (Teo et al., 2003) and firms may feel these pressures as a force, a persuasion, or as an invitation to join in collusion which they did not intend to do. Some firms are coerced into adopting practices or actions to avoid punishment (Grewal \& Dharwadkar, 2002) and sanctions (Scott, 1995). For instance, prior studies have shown that regulatory pressure drives firms to adopt environmental practices (Buysse \& Verbeke, 2003; Yalabik \& Fairchild, 2011). Firms are affected by various government regulations that have implications for their business. These regulatory pressures from government force firms to follow in order to achieve compliance (Druker et al., 2005; Goodman et al, 1998; Patton \& Worthington, 2003; Petts et al., 1999; Vickers et al., 2005). According to Zhu and Sarkis (2007), firms may have better environmental performance when facing higher regulatory pressure.

In addition, Darnell (2006) observes that customers can play a vital role in pressurizing organizations to adopt environmentally friendly practices and strategies. Due to the burgeoning global environmental crisis, customers are now putting more attention on environmental issues (Follows \& Jobber, 2000). Heavy promotion through the media and information technology has raised consumers' awareness regarding their roles in contributing to save the environment. One of these roles is to consume green products or services (Eze et al., 2011). Previous studies have shown that there is a growing demand for green products or services from consumers (Clark, 2009; Environmental Leader, 2009; The Star, 2010). Consumers are also concerned about the level of involvement of businesses in adopting environmentally friendly activities (De Pelsmacker et al., 2005). With that, one of the challenges for a business aiming to be sustainable is to deal with the growing demand from consumers for businesses to practice environmental protection (Follows \& Jobber, 2000). According to Manaktola and Jauhari (2007), the environmental performance of a firm can be considered as one of their products' attributes that deliver benefits to customers. This environmental performance includes green practices firms employ, such as water disposal or using alternative sources of energy. The growing awareness of people about the damage caused in the environment by regular business has led to more and more customers looking for firms that are adopting green practices to save the environment (Manaktola \& Jauhari, 2007). Based on the aforementioned, in this study, coercive pressure arises from regulatory pressure and customer pressure. This leads to the following hypotheses:

H1: Coercive pressure has a positive and significant relationship with green practices adoption.

H1a: Regulatory pressure has a positive and significant relationship with green practices adoption.

H1b: Customers' pressure has a positive and significant relationship with green practices adoption. 


\section{Normative Pressure}

Normative pressure refers to pressure that stems from professionalization, which can be interpreted as the collective struggle of people who hold an occupation to define the conditions and methods of their work, and also to establish a cognitive base and legitimation for their occupational autonomy (Cheng \& Yu, 2008; DiMaggio \& Powell, 1983; Larson, 1991). DiMaggio and Powell (1983) observed two sources of professionalization: formal education and the growth of a professional network of personnel within an organization. When the personnel (i.e., managers, key staffs) are professionalized (i.e., they have similar formal education and attributes), they tend to view problems in a similar fashion, see the same policies, procedures, and structure as normatively sanctioned and legitimated, and approach decision making with a similar mindset (DiMaggio \& Powell, 1983, pp. 153). When personnel within an organization are struggling to achieve the results of the same expectations, these expectations will become shared norms, which in turn influence organization attitudes toward the maintenance of relationship networks, and curtail behaviors that promote individual goals (Heide \& John, 1992). Conforming to these shared norms puts the firm in a position to assure constituents in the field that it maintains procedural legitimacy (John et al., 2001; Zsidisin et al., 2005). According to Cheng and Yu (2008), an organization's adoption of a new practice is related to its managers' personal traits. In this study, normative pressure refers to pressure from employees and managers' personal attributes (i.e., educational background and work experience) in influencing fast food restaurants to adopt green practices. Therefore, the above discussion leads to the following hypotheses:

H2: Normative pressure has a positive and significant relationship with green practices adoption.

H2a: Pressure from employees has a positive and significant relationship with green practices adoption.

H2b: Managers' attributes have a positive and significant relationship with green practices adoption.

\section{Mimetic Pressure}

According to DiMaggio and Powell (1983), a mimetic process occurs when an organization models itself on other organizations when that organization is in an uncertain environment (i.e., the organization's goals are ambiguous and it has a poor understanding of organizational technologies). Organizations tend to model themselves after other organizations they believe are well managed and able to survive in a competitive environment. These organizations do not intentionally serve as models, but other organizations view them as a convenient source of information to reduce uncertainty. According to Jennings and Zandbergen (1995), firms sometimes implement programs (e.g., environmentally friendly programs, green products, and environmental marketing programs) without studying the impacts, but rather due to competitive pressure. Hence, the following hypothesis is proposed:

H3: Mimetic pressure has a positive and significant relationship with green practices adoption.

H3a: Competitors' pressure has a positive and significant relationship with green practices adoption.

Based on a review of the relevant literature and discussion on institutional theory, it is widely accepted that this theory has been widely adopted to study how environmental pressures (i.e. institutional pressures) affect managerial actions in shaping organizational structures and actions (Goodstein, 1994; Greening \& Gray, 1994). Hence, we believe that institutional theory best suits the purpose of our study. In addition, using institutional theory to study environmental issues (i.e., environmental practices, green practices) is consistent with previous research (Babiak \& Trendafilova, 2011; Brammer et al., 2012; Clemens \& Douglas, 2006).

With that, the proposed conceptual framework for this paper is shown in Figure 1. 


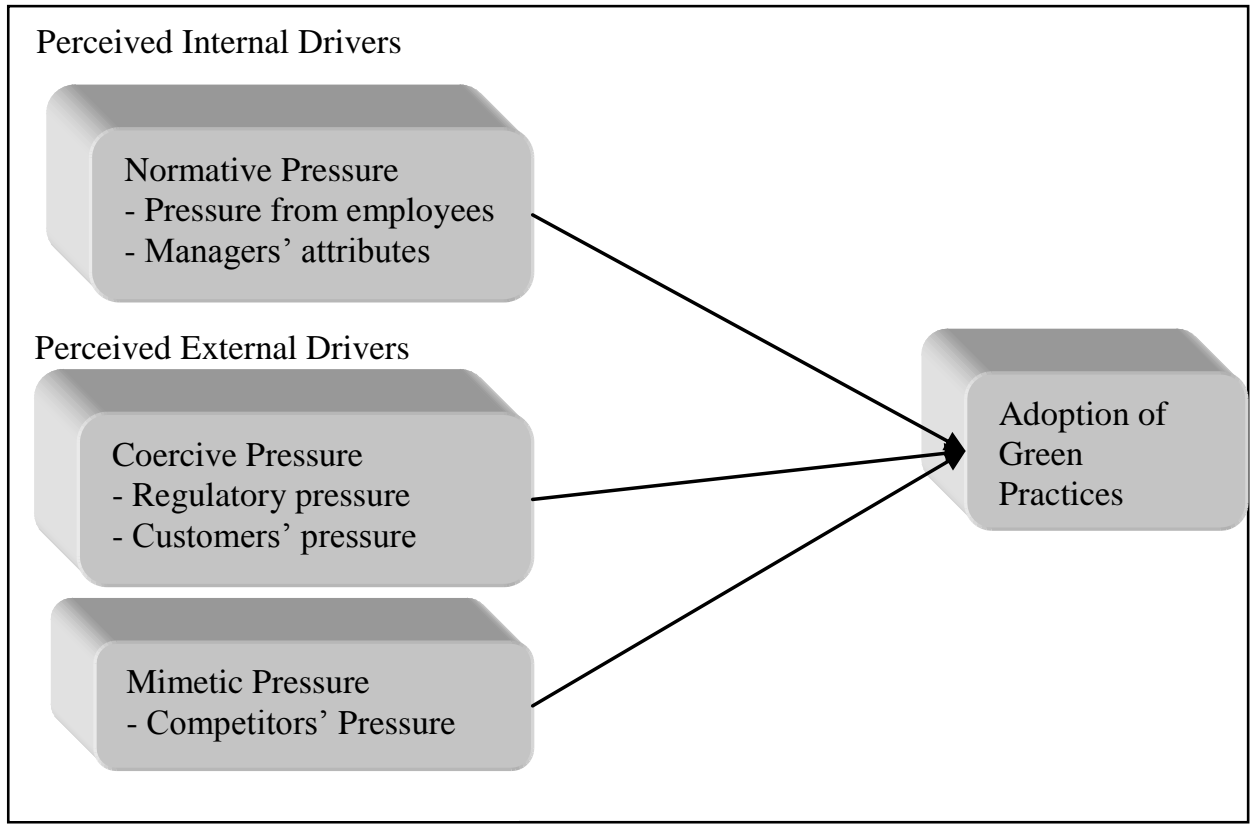

Figure 1. Proposed Conceptual Framework

\section{RESEARCH METHODOLOGY}

The unit of analysis for this study will be fast-food restaurants in Malaysia. The respondents to the survey will be managers of fast-food restaurants. Hence, the population frame should be drawn from an existing formal directory of the fast-food industry, such as Euromonitor International, which is the world leader in strategic research for consumer markets. Several previous researchers have also utilized Euromonitor reports in their studies (Ryan et al., 2010; Ungku et al, 2011; Bruwer et al., 2011). We will employ cluster sampling in this study to select burger and chicken fast-food outlets as they occupy a majority share among all fast-food outlets. To measure the goodness of data, reliability and validity tests are compulsory (Sekaran \& Bougie, 2010). Cronbach's Alpha can be used in measuring the reliability of inter-item consistency among variables (Nunally, 1978). Factor analysis needs to be conducted to measure the validity of each construct (Field, 2009). Structural Equation Modeling (SEM) can also be used to measure the causal relationship between independent variables (i.e. pressure from employees, managers' attributes, regulatory pressure, customers' pressure, competitors' pressure) and the dependent variable (adoption of green practices).

\section{CONCLUSION}

This study contributes to the limited studies of the food service industry (Line \& Runyan, 2011; Tsang, 2010; Wang, 2012), particularly within the Malaysian context. This study highlights several benefits of being a green restaurant (e.g., cost savings, better firm reputation, sustainability, saving the environment, etc.) which might enhance managers' understanding of the importance and impacts of adopting green practices. In addition, the increasing number of fast-food restaurants and the growing demand for fast food will definitely require increasing amounts of energy. The impact will be huge if no measures are taken to reduce energy consumption in the food service industry. Moreover, testing this framework will serve as a guide for the food service industry, especially in understanding the perceived internal and external pressures applied to it. Lastly, we hope that when this study is concluded, we will be able to assess the hypothesized relationships outlined in this paper and consequently be able to provide detailed key research and practical implications, including suggestions for future research agendas. 


\section{AUTHOR INFORMATION}

Chai Har Lee is a lecturer at Multimedia University, Malaysia. Her main area of research interest is green marketing, sustainability, and renewable energy. E-mail: chaiharlee@ gmail.com (Corresponding author)

Dr. Nabsiah Abdul Wahid is an Associate Professor and lecturer at the Graduate School of Business at Universiti Sains Malaysia. Her areas of research interest are services marketing, service quality, green marketing and consumer behavior. E-mail: nabsiah@ hotmail.com; nabsiah@usm.my

Dr. Yen Nee Goh is a Senior Lecturer at Universiti Sains Malaysia. Her areas of research interest are environmental management systems in SMEs, green marketing, and consumer behavior. E-mail: gohyennee@gmail.com; yngoh@usm.my

\section{REFERENCES}

1. $\quad$ Aldrich, H. (1979). Organizations and environments. Englewood Cliffs, NJ: Prentice Hall.

2. Babiak, K. \& Trendafilova S. (2011). CSR and environmental responsibility: motives and pressures to adopt green management practices. Corporate Social Responsibility and Environmental Management 18 (1), 11-24. doi:http://10.1002/csr.229

3. Brammer, S., Jackson, G. \& Matten, D. (2012). Corporate social responsibility and institutional theory: new perspectives on private governance. Socio-Economic Review, 10, 3-28. doi:http:// 10.1093/ser/mwr030

4. Bruwer, J. Saliba, A. \& Miller, B. (2011). Consumer behaviour and sensory preference differences: implications for wine product marketing. Journal of Consumer Marketing, 28/1, 5-18. doi: http://10.1108/07363761111101903

5. Business and the Environment. (2008). Serving up a Green Menu - The Green Restaurant Association. XIX (11), 1-4.

6. Buysse, K. \& Verbeke, A. (2003). Proactive Environmental Strategies: A Stakeholder Management Perspective. Strategic Management Journal, 24(5), 453-470. doi: http://10.1002/smj.299

7. Carroll, G. R. \& Delacroix, J. (1982). Organizational mortality in the newspaper industries of Argentina and Ireland: an ecological approach. Administrative Science Quarterly, 27, 169-198. Available at: http://www.jstor.org/discover/10.2307/2392299?uid=3738672\&uid=2129\&uid=2134\&uid=2\&uid=70\&uid $=4 \& \operatorname{sid}=56276881073$

8. Cheng, H-L. \& Yu, C-M. J. (2008). Institutional pressures and initiation of internationalization: evidence from Taiwanese small-and medium-sized enterprises. International Business Review, 17, 331-348. doi: http://10.1016/j.ibusrev.2008.01.006

9. Chou, C-J., Chen, K-S. \& Wang, Y-Y. (2012). Green practices in the restaurant industry from an innovation adoption perspective: Evidence from Taiwan. International Journal of Hospitality and Management, 31, 703-711. doi: http://10.1016/j.ijhm.2011.09.006

10. Clark, S. (2009). 2009 Greendex survey of 17 countries finds increase in green consumer behavior worldwide. Retrieved 12 February 2012, from: http://www.eurekalert.org/pub releases/2009-05/ngs2gs051309.php

11. Clemens, B. \& Douglas, T. (2006). Does coercion drive firms to adopt 'voluntary' green initiatives? Relationships among coercion, superior firm resources, and voluntary green initiatives. Journal of Business Research, 59 (4), 483-491. doi: http://dx.doi.org/10.1016/j.jbusres.2005.09.016,

12. Darnell, N. (2006). Why firms mandate ISO 14001 certification? Business \&Society, 45 (3), 354-81. doi: http:// 10.1177/0007650306289387

13. De Pelsmacker, P., Driesen, L. \& Rayp, G. (2005). Do consumers case about ethics? Willingness to pay for fair-trade coffee. The Journal of Consumer Affairs, 39, 363-385. Available at: http://www.people.fas.harvard.edu/ hiscox/Depelsmacker.pdf

14. DiMaggio, P. J., \& Powell, W. W. (1983). The iron cage revisited: Institutional isomorphism and collective rationality in organizational fields. American Sociological Review, 48: 147-160. Available at: http://www.ics.uci.edu/ corps/phaseii/DiMaggioPowell-IronCageRevisited-ASR.pdf

15. Druker, J., G. White \& C. Stanworth (2005), Coping with Wage Regulation. International Small Business Journal, 23(1), 5-25. Available at: http://isb.sagepub.com/content/23/1/5.full.pdf 
16. Euromonitor International (22 August 2011). Fast food in Malaysia. Available from: http://www.portal.euromonitor.com/Portal/Pages/Analysis/AnalysisPage.aspx

17. Environmental Leader. (2009). Consumer Survey: Growth of 'Green' Consumption On Hold. Retrieved 12 February 2012 from http://www.environmentalleader.com/2009/03/06/consumer-survey-growth-of-greenconsumption-flounders/

18. Environmental Leader. (2012). Evaluating the ROI in going “green”. Retrieved 20 June 2012 from http://www.environmentalleader.com/2012/06/19/evaluating-the-roi-in-going-green/

19. Eze, U. C. Chong, M. P. F. \& Lee, C. H. (2011). Consumers' Willingness to Engage in Green Buying Behaviour in Malaysia, in the Proceedings of the $6^{\text {th }}$ Asia Pacific Retail Conference, Kuala Lumpur, Malaysia.

20. Field, A. P. (2009), Discovering Statistics Using SPSS: and sex and drugs and rock ' $n$ ' roll (3rd Ed.), Sage, London.

21. Follows, S.B. \& D. Jobber, (2000). Environmentally responsible purchase behavior: A test of a consumer model. Euro. J. Mark., 34(5-6): 723-746. doi: http:// 10.1108/03090560010322009

22. Goodstein, J. D. (1994). Institutional Pressures and Strategic Responsiveness - Employer Involvement in Work Family Issues. Academy of Management Journal, 37(2): 350-382. Available at: http://www.jstor.org/stable/256833

23. Grewal, R. \& Dharwadkar, R. (2002). The role of the institutional environment in marketing channels. Journal of Marketing, 66, 82-97. Available at: http://www.personal.psu.edu/rug2/Grewal\%20\&\%20Dharwadkar\%202002\%20JM.pdf

24. Greening, D. W., \& Gray, B. 1994. Testing a model of organizational response to social and political issues. Academy of Management Journal, 37(3): 467-498. Available at: http://jaylee.business.ku.edu/MGMT\%20916/PDF/Greening\%201994\%20AMJ.pdf

25. Goodman, J., Earnshaw, J. Marchington, J. \& Harrison, R. (1998). Unfair Dismissal Cases, Disciplinary Procedures, Recruitment Methods and Management Style: Case Study Evidence from Three Industrial Sectors, Employee Relations, 20(6), 536-550. doi: http://10.1108/01425459810247297

26. Hatch, M.J. (1997), Organizational Theory: Modern, Symbolic, and Postmodern Perspectives, Oxford University Press, New York, NY.

27. Heide, J.B. \& John, G. (1992). Do norms matter in marketing relationships? Journal of Marketing 56 (2), 32-44. Available at: http://research3.bus.wisc.edu/file.php/153/Do_Norms_Matter.pdf

28. Hoffman, A.J. (1997), From Heresy to Dogma: An Institutional History of Corporate Environmentalism, New Lexington Press, San Francisco, CA.

29. Jang, Y. J., Kim, W. G. \& Bonn, M. A. (2011). Generation Y consumers' selection attributes and behavioral intentions concerning green restaurants. International Journal of Hospitality Management, 30 , 803-811. doi: http://10.1016/j.ijhm.2010.12.012

30. Jennings, P. D. \& Zandbergen, P. A. (1995). Ecologically Sustainable Organizations: An Institutional Approach. Academy of Management Review, 20(4):1015-1052. doi: http:// 10.2307/258964

31. John, C.H.S., Cannon, A.R. \& Pouder, R.W., (2001). Change drivers in the new millennium: implications for manufacturing strategy research. Journal of Operations Management, 19, 143-160. doi: http://dx.doi.org/10.1016/S0272-6963(00)00054-1

32. Kasim, A. (2009). Managerial attitudes towards environmental management among small and medium hotels in Kuala Lumpur. Journal of Sustainable Tourism, 17(6), 709-725. doi: http://10.1080/09669580902928468

33. Larson, A. (1991). Partner networks: Leveraging external ties to improve entrepreneurial performance. Journal of Business Venturing, 6(3), 173-189. Available at: http://EconPapers.repec.org/RePEc:eee:jbvent:v:6:y:1991:i:3:p:173-188

34. Lee, C. H., Wahid, N. A. \& Goh, Y. N. (2012). Assessing determinants of green practices adoption: a conceptual framework, Elixir Journal, 45, 7760-7766. Available at: http://elixirjournal.org/articles_view_detail.php?id=1990\&mode=pdf

35. Line, N. D. \& Runyan, R. C. (2011). Hospitality marketing research: recent trends and future directions, International Journal of Hospitality Management, 31(2), 477-488. doi: 10.1016/j.ijhm.2011.07.006

36. Manaktola, K. \& Jauhari, V. (2007). Exploring consumer attitude and behaviour towards green practices in the lodging industry in India. International Journal of Contemporary Hospitality Management, 19 (5), $364-$ 377. doi: http:// 10.1108/09596110710757534 
37. Meyer, J. W., \& Rowan, B. (1977). Institutionalized organizations: Formal structure as myth and ceremony. American Journal of Sociology, 83: 340-363. Available at: http://www.jstor.org/stable/2778293

38. Mohindra, K. S. (2008). Greening Public Health Conferences: Educating Ourselves. Health Education, 108 (4): 269-71. doi: http:// 10.1108/09654280810884151

39. Norton, J. (2010). Interview with Gareth Kane, author of The Three Secrets of Green Business. Strategic Decision, 26 (8), 37-39. doi: http://10.1108/02580541011055733

40. Nunnally, J.C. (1978), Psychometric Theory (2nd ed.), McGraw Hill, New York.

41. Patton, D. \& Worthington, I. (2003). SMEs and Environmental Regulations: A Study of the UK ScreenPrinting Sector, Environment and Planning C: Government and Policy, 21(4), 549-566. Available at: http://www.envplan.com/abstract.cgi?id=c0321

42. Petts, J., Herd, A., Gerrard, S. \& Horne, C. (1999). The Climate and Culture of Environmental Compliance within SMEs, Business Strategy and the Environment, 8, 14-30. doi: http:// 10.1002/(SICI)10990836(199901/02)8:1<14::AID-BSE175>3.0.CO;2-4

43. Powell, W.W. \& DiMaggio, P.J. (1991). The New Institutionalism in Organizational Analysis, University of Chicago Press, Chicago, IL.

44. Ryan, C., Ghazali, H. \& Mohsin, A. (2011). Determinants of intention to leave a non-managerial job in the fast-food industry of West Malaysia. International Journal of Contemporary Hospitality Management, 23 (3), 344-460. doi: http://10.1108/09596111111122523

45. Schelling, T. C. (1978) Micromotives and Macrobehavior. New York: Norton.

46. Scott, W. R. (2001). Institutions and organizations (2nd ed.). Thousand Oaks, CA: Sage.

47. Scott, W.R. (1995), Institutions and Organizations, Sage, Thousand Oaks, CA.

48. Sekaran, U., \& Bougie, R. (2010), Research methods for business: A skill building approach, John Willey \& Sons, Great Britain.

49. Selznick, P. (1957), Leadership in Administration: A Sociological Perspective, Harper \& Row, New York, NY.

50. Siti-Nabiha, A. K., George, R. A., Wahid, N. A., Amran, A., Abustan, I. \& Mahadi, R. (2011). A field survey of environmental initiatives at selected resorts in Malaysia. World Applied Sciences Journal, 12, 5663. Available at: http://www.idosi.org/wasj/wasj12(T\&H)11/8.pdf

51. Suchman, M.C. (1995). Managing legitimacy: strategic and institutional approaches. Academy of Management Review, 20 (3), 571-610. Available at: http://www.jstor.org/stable/258788

52. Sulaiman, S. \& Haron, M. S. (2011). Foodscapes: The effects towards future behavioral intentions in casual dining restaurant. Proceedings of the $9^{\text {th }}$ Asian Academy of Management International Conference, October 14-16, 2011, Penang, Malaysia.

53. Teo, H.H., Wei, K.K. \& Benbasat, I. (2003). Predicting intention to adopt interorganizational linkages: an institutional perspective. MIS Quarterly, 27(1), 19-49. doi: http://10.2307/30036518

54. The Star (2010). Green products on the rise, report says. Retrieved 12 February 2012, from http://www.thestar.com/article/881465--green-products-on-the-rise-report-says

55. Tsang, M. L. (2010). An assessment of cause and effect decision making model for firm environmental knowledge management capacities in uncertainty. Environmental Monitoring and Assessment, 161, 549564. doi: http://10.1007/s10661-009-0767-2

56. Ungku, Z. A. U. F., Boo, H. C, Sambasivan, M. \& Salleh, E. (2011). Foodservice hygiene factors - the consumers perspective. International Journal of Hospitality Management, 30, 38-45. doi: http://dx.doi.org/10.1016/j.ijhm.2010.04.001

57. Vickers, I., P. James, D. Smallbone \& Baldock, R. (2005). Understanding Small Firm Reponses to Regulation: The Case of Workplace Health and Safety, Policy Studies, 26(2), 149-169.

58. Wang, R. (2012). Investigations of important and effective effects of green practices in restaurants. Procedia - Social and behavioral Sciences, 40. 94-98. doi: http://10.1016/j.sbspro.2012.03.166

59. Yalabik, B. \& Fairchild, R. J. (2011). Customer, regulatory and competitive pressure as drivers of environmental innovation. International Journal of Production Economics, 131, 519-527. doi:10.1016/j.ijpe.2011.01.020

60. Zhu, Q. \& Sarkis, J. (2007).The moderating effects of institutional pressures on emergent green supply chain practices and performance. International journal of production research, 45 (18-19), 4333-4355. doi: http://10.1080/00207540701440345 
61. Zsidisin, G.A., Melnyk, S.A. \& Ragatz, G.L. (2005). An institutional theory perspective of business continuity planning for purchasing and supply management. International Journal of Production Research, 43 (16), 3401-3420. doi: http://10.1080/00207540500095613

62. Zucker, L.G. (1987), Institutional theories of organization. Annual Review of Sociology, 13, 443-64. doi: http:// 10.1146/annurev.so.13.080187.002303 